\title{
The Impact of Management Accounting Practices on the Performance of Manufacturing Firms; An Empirical Evidence from Ghana
}

\author{
Joseph Adu-Gyamfi * Kong Yusheng Wayne Chipwere \\ School of Finance and Economics, Jiangsu University \\ No. 301 Xuefu Road, Zhenjiang City, Jiangsu Province, China 212013
}

\begin{abstract}
This study aimed at examining the impact of management accounting practices on performance of manufacturing firms in Ghana. The study use a quantitative research approach and data was collected from 200 manufacturing firm's managers who were selected by means of the probability simple random sampling technique The Statistical Package for the Social Sciences (SPSS), version 18.0, was used to analyze data. Regression analysis was undertaken in order to check the association between management accounting practices and performance The study results shows that costing system, budgetary system, performance evaluation system, strategic management and information for decision making are the key management accounting practices mostly adopted by manufacturing firms in Ghana and these management account practices positively influences the performance of manufacturing firms in Ghana. The study then recommends that most of these management accounting practices has to be adhered to if managers want to increase performance.
\end{abstract}

Keywords: Management Accounting Practices, Costing System, Budgeting System, Strategic analysis, Performance, Ghana

DOI: $10.7176 / \mathrm{RJFA} / 11-17-13$

Publication date:October $31^{\text {st }} 2020$

\section{Introduction}

The impact of the manufacturing industry in every countries economy cannot be overlook, however for a better performance from these manufacturing firms, management accounting practices to access better operations is very needful. It is recognize that management accounting practices are important to the success of the organization (Horngren, et al., 2009). The Manufacturing sector is a key driver of industrialization; however, in the developing world with much emphasis on African, the sector has not achieved desirable sustainable performance, An adoption of effective management accounting practices by manufacturing firms is an obvious means to approach the challenges of competition, change and costing so as to improve performance (Horngren, Datar, Foster, Rajan, \&.Ittner, 2009). Management accounting practices and techniques help management of organizations including manufacturing firms to plan, direct and control operating costs and to achieve optimal performance (Gichaaga, 2013)

Management accounting is the "application of appropriate techniques and concepts in processing the historical and projected economic data of an entity to assist management in establishing a plan for reasonable economic objectives and in the making of rational decisions with a view towards achieving these objectives" (Gichaaga, 2014, p.12). Most Companies use management accounting practices to assess their operations. These include budgeting, variance analysis and breakeven analysis. These methods help organizations to plan, direct and control operating costs and to achieve profitability. Effective management accounting practices scan operational environment and provide management with information from its environment to facilitate decision-making and achieve competitive advantages and change (Smith, 2009). According to McWatters (2001), management accounting adapts to organizational change which are often driven by three major forces: technological change, globalization, and customer needs. A critical review of these characteristics of management accounting practice show that, it is capable to mitigate the factors which cause the poor performance of manufacturing sector in most economy in world.

Association of Ghana Industries AGI (2013) attributed the poor performance of most manufacturing firms in Ghana to competition, technological change, power and cost of operation among others. Obed (2016) argued that cost of operation can be a driving force of the poor performance, with this assertion manufacturing sector requires effective cost control system to achieve desired results thus Cost control form part of effective management accounting practice. This seeks to suggest that there is relationship between management accounting practices and performance of manufacturing firms.

The Association of Ghana Industries (AGI) has bemoaned that the manufacturing sector of Ghana continues to constrict. Is of this concern that the AGI has always voicing their concerns, when the manufacturing sector recorded an unprecedented $-8 \%$ growth rate in 2015 (Obed, 2016). Notwithstanding the current performance trend, it is believed that the Ghanaian manufacturing sector still has potentials to achieve desirable results and contribute 
significantly to economic growth if the challenges are addressed. This study is to explore management accounting practices and examine the extent to which the level of adoption affects the performance of manufacturing firms in Ghana and the relationship that exist between effective management accounting practices and performance of manufacturing firms in Ghana. Following both theoretical evidences and authoritative assertions (it is clear that management accounting practices can influence performance of manufacturing sector. However, there exists limited empirical literature in relation to the sector in Ghana. Although it is easy to obtain prior studies on management accounting practice it is equally difficult to associate them with the manufacturing sector in Ghana. Most of the few studies on management accounting practices associated to manufacturing sector in Ghana include Abor and Effah (2011); Amoako (2013); Mbawuni and Anerte (2014).

However, it is also necessary to mention that, within the Ghanaian ambience, there is dearth of Research studies that have shed light on the impact of management accounting practices on the performance of manufacturing firms in Ghana. Most subsist research literature on accounting in Ghana manufacturing companies stands to be more partial toward the area of, financial accounting, information technology adoption as well as research in credit accessibility for manufacturing companies, more so only few exists in regard to effects of management accounting practices on performance of manufacturing companies in Ghana.

In light of the above gap the researchers are convinced that there is dearth in study area and need to be studied more. Hence the need for the current study. Moreover, it is also essential to mention that, there is limited literature that focuses on management accounting practices as predictor variables of performance. Therefore, it is because of this reason we decide to use this study to remedy the lack of research by investigating the impact of management accounting practices on the performance of manufacturing firms in Ghana.

The study will benefit various other companies in Ghana as they will understand the methods and tools available for them as far as controlling costs are concerned. The study will also benefit scholars and academicians interested in pursuing a study in accounting and especially management accounting as it will form a foundation for other studies.

The findings can be specifically informative for policy makers' intent on developing management accounting skills among Ghanaian manufacturing firms. The findings of this study will also bring to the attention of development agencies the current Management accounting practices of manufacturing firms and how it affects their performance. As a result, it will serve as the basis for organizing training programs, seminars and workshops on effective management accounting practices.

The study was positioned within a quantitative research approach and data was collected from 200 manufacturing firm's managers who were selected by means of the probability simple random sampling technique. The Statistical Package for the Social Sciences (SPSS), version 18, was used to analyze data. Regression analysis was undertaken in order to check the association between management accounting practices and business performance. The hypothesized relationships in the research model were assessed using multiple regression analysis.

The rest of the paper introduces literature and empirical studies in section 2. Section 3 exhibits population sample, data collection and methodology. In section 4, results and discussions. Our final section presents conclusion, limitations and recommendations.

\section{Literature and empirical review \\ 2.1 Theoretical Review}

Theoretical postulations or justifications are required for the evaluation of relationships between the various variables in the study. For this reason the study adopts the institutional theory, the contingency theory and adopted theory. These theories help develop the key constructs and the interrelationships between the proposed concepts.

\subsubsection{Institutional Theory of Organizations}

The institutional theory of organizations is an adaptive change process framework. It examines the impact of external environment factors and market conditions on organizational change and development (Barnett \&Caroll,1995). The institutional theory depends, heavily, on the social constructs to help define the structure and processes of an organization (Scott, 2001). Using institutional theory, Burns and Scapens (2000) have conceptualized management accounting change as change in organizational rules and routines. Under old institutional economic (OIE) theory, management accounting is conceived as a routine, and potentially being institutionalized, management accounting practices can both shape and be shaped by institutions which govern organizational activity. In OIE there are three dichotomies which offer insights into the process of management accounting change. They are: (1) formal versus informal change; revolutionary versus evolutionary change; and (3) regressive versus progressive change (Burns \&Scapens, 2000). Burns and Scapens (2000) conceptualized the formal versus informal change dichotomy as the most appropriate for explaining the relationship between management accounting and organizational change. The theoretical assumption underlying the first dichotomy provides that there is a relationship between the level of management accounting practices and organization performance 
Formal and informal management accounting change is used to imply that change is not specifically directed (formal change), but may evolve out of the intended actions of the individuals who are enacting and reproducing organizational routines (informal change) (Meyer \& Rowan, 1977). Mat(2010), formal change occurs through the introduction of new management Accounting systems and techniques, which in turn, engender the organization to change including organizational performance. Therefore, management accounting practices include formal practices such as costing system, costing techniques, budgetary system, performance evaluation system and strategic accounting (Smith et al. 2005). These theoretical management accounting practices are explored among the manufacturing firms within the study frame. This provides theoretical concepts underlying one of the objectives of study which focuses on identifying the Manufacturing Accounting Practices adopted by these firms.

\subsubsection{Contingency Theory}

The Contingency theory posits that an appropriate match between organizational characteristics to contingencies will improve organizational effectiveness (Morton \& Hu, 2008). However, in the contingency theory of organizations, there is no universally acceptable model of the organization that explains the diversity of organizational systems design of one organization to the other. This can be related to organizations operating in different industries or sectors. Otley (1980) applied contingency theory to management accounting practices and explained that there is no single general standard accounting practice that can be applied to all organizations. He explain that in 'essence, each organization will have its own management accounting practices. The theory looks at certain influential factors that will assist management to decide on an appropriate management accounting practice. These factors can either be technological changes and the infrastructure of an organization.'

A contingency perspective suggests that effective management accounting systems should align with both internal and external factors (Battilana \&Casciaro, 2012). The internal factors can be likened to the ownership structure or management and key personnel similarly; the external factors can be likened to technological change, competition and market forces. This study thus aims to empirically investigate the validity of contingency central theorem that organizational performance depends on the fit between organizational context and structure. Contingency theory is relevant to this study, in that it is paramount to explain how accounting systems might be affected by the fit between environmental and organizational factors.

\subsubsection{Adapted Theory}

Looking at the effect of the impact outward environmental factors and market conditions on organizational change and development is very necessary to the performance of manufacturing firms. This creed is derived from the institutional theory which subjects an adaptive change as a means of determining high performance by manufacturing firms. From such a creed, the study objective of identifying factors that influence or affect management accounting practices within manufacturing industries is easily developed.so with the adapted theory it seek to explain how these manufacturing firms are able to adapt to changes that mostly happens These factors are market conditions, external environmental factors and structural or internal organizational change. It stands to reason from the institutional theory that when organizations adapt quickly and efficiently to these conditions, it would be easy to use new trend of management accounting procedures to boost their performance.

\subsection{Empirical Review}

Various studies have been carried out by various authors across the world on management accounting practices. To help direct the focus of the study and provide a basis for comparison of the findings of this research, we review certain literature in relation to management accounting practices

Adler, Everett, and Waldron (2000) conducted a survey involving management accountants of New Zealand manufacturing companies. The non-probability judgement sampling technique was adopted for the sampling. Data were gathered from 165 manufacturing sites in New Zealand, which were chosen as representative of companies confronted with major environmental change and structural reform. The managers were asked to indicate which techniques were adopted in their company. The findings disclosed that the New Zeeland manufacturing firms usually adopted traditional management accounting techniques, like standard costing, direct costing and full costing than advanced management accounting techniques, like strategic management accounting.

Another closely related study was performed by Abdel-Kader and Luther (2006). The authors evaluated the management accounting practices (MAPs) within the food and drinks industry in the U.K. in an attempt to understand the level of MAP's sophistication in addition to the factors that influence implementation of MAPs in this industry. The study adopted a survey research methodology. A five-point Likert scale questionnaire (1 indicating never and 5 indicating very often) consisting of 38 items which required the respondents to indicate the frequency of use of the various MAPs was used for the data collection. They were as well required to assess the importance of each practice/technique by rating them as 'not important, moderately important or important. The questionnaires were sent to 650 executives of the industry and 245 were received, representing a response rate of 38 percent. The results revealed that while the firms moved into a more uncertain environment, the level of sophistication of management accounting practices increased. Similarly, while their power relative to customers diminished, firms moved up the stages of evolution. The results also revealed that the management accounting 
systems used in most food and drinks companies were not particularly sophisticated. The study finally indicated that there was little evidence of management accounting directly connected with 'value creation' for the food and drinks industry in general

Another related study was carried out by Liaqat (2006) to determine the application of contemporary management accounting techniques in Indian companies. A survey research design was employed. The study targeted 530 member companies of India's National Association of Financial Directors and Cost Controllers. Sixty three (63) companies responded, representing a response rate of about $12 \%$. Stratified sampling technique was used to divide the sampling points into two strata, i.e. ABCM user firms and Non ABCM user firms. A five point Likert scale questionnaire was employed. The study focused on finding evidence on how widely contemporary and traditional management accounting practices were employed by Indian companies. It was discovered that improvement of general cost reduction and profitability were the motive behind the utilization of management accounting in Indian firms. The study also discovered a positive relationship between the adoption of ABC and firm characteristics such as pressure of competition, degree of customization, proportion of overhead to total cost, and business size. None of the variations, however, was found to be at $10 \%$ significant level.

A study was also conducted by Waweru (1999) to examine the management accounting practices as well as management accounting techniques employed by publicly listed companies in Kenya together with the extent of their utilization. In addition, the type of management accounting reports produced and the frequency of their production were evaluated. The study was based on the hypothesis that the success of any company within a competitive environment largely depends on the availability of quality and timely information for the process of decision making.

A study by Amoako (2013) examined the accounting practices among SMEs in Kumasi (Ghana) through data based on responses to a structured questionnaire from 210 SMEs. Although the study was situated within Kumasi metropolis, the population was not industrial specific and this may affect the findings because of differential characteristics of the various industries the SMEs may belong. Again, the study limited accounting practices to records keeping. To ascertain robust results, this study is focused on the manufacturing sector with attention on the management accounting practices and the consequence on performance

Another study conducted within the Ghanaian context is that of Mbawuni and Anertey (2014). They examined the application of a broad range of management accounting practices used by telecommunication companies in Ghana. The study used a cross-sectional survey that yielded 37 useable questionnaires from respondents with varied professions in accounting and finance in MTN Ghana, a leading Telecommunication company in Ghana. The findings show that the most used category of MAPs is strategic analysis practices, traditional budgeting techniques, and relies more on financial measures than non-financial measures. Mbawuni and Anertey, (2014) study suffered methodological flaws. The topic of the article is not adequately represented by the scope of the study.

The unavailable of specific empirical evidences on the subject matter cause interest groups and parties to turn to literatures from other parts of the world which may not be representative to the Ghanaian settings. For instance, although Waweru (1999) was undertaken in Kenya, the fact that there are differences in the geographical conditions between Ghana and Kenya limits the extent to which the study findings can be generalized to the Ghanaian settings. Also, Waweru (1999) examined the relationships between management accounting practices and organizational performance, they obtained mixed findings. In response to these findings, this study aims to find out whether the situation is different in Ghana. It thus aims to investigate the adoption rate of management accounting practices and their influence performance of manufacturing firms in Ghana.

\subsection{Manufacturing Sector in Ghana}

Most manufacturing firms in Ghana are a subsidiary of multinationals. With the current government flagship program of one district one factory is believed that most district will be fill with a lot of manufacturing firms. most of these firms can be categories as represented in the Ghana association of manufacture's listings; food and beverages processing, Paper and paper board, Wood products Pharmaceutical and medical equipment, Leather products, Chemical and allied, Textiles, Tobacco, Plastics and rubber (Association of Manufacturers, 2013). Association of Ghana Industries (AGI) (2013), indicated that poor performance include competition, continuous technological challenges, poor power stability and cost of business. These problems in the manufacturing sector have caused a lot of the firms within the sector to fold-up for instance when the country was hit by massive power instability between 2014 and 2016 which affected most manufacturing firms The manufacturing sector has been growing by 3.3 percent, while other industrial sectors, such as mining, water production and construction have grown by 9.1 per cent on average between 2003 and 2013(Davies \& Karr, 2015) The relative share of the contribution of the manufacturing to GDP has declined, from about $10 \%$ in 1990 to $6.9 \%$ in 2012 and 2013. Most of this decline seems to have happened after 2007 according to Davies and Karr (2015). But currently indeed, the manufacturing sector grew by an impressive $9.5 \%$ in 2017, up from $7.9 \%$ in 2016 and $3.7 \%$ in 2015 . As the African Development Bank (AfDB) has noted, the value of Ghana's machinery imports increased four-fold 
between 2000 and 2017 to $\$ 670 \mathrm{~m}$, reflecting the country's growing industrial capacity. But currently because the power is stable there is a bit of rise in most production of manufacturing firms in Ghana

\subsection{Management Accounting Practices}

Ittner and Larcker (2002) defined management accounting practices as a variety of methods specially considered for manufacturing businesses so as to support the organization's infrastructure and management accounting processes. Management accounting practices can include budgeting, performance evaluation, and information for decision-making and strategic analyses, among many others. Management accounting is a branch of accounting that produces information for managers and forms an important integral part of the strategic process within an organization. It involves the process of identifying, measuring, accumulating, analyzing, preparing, interpreting, and communicating information that helps managers fulfill organizational objectives (Hilton \& Platt, 2011; Horngren, Sundem, Stratton, Burgstahler\&Schatzberg, 2007).

Gichaaga(2014) asserts that management accounting practices can consist of performance evaluation, budgeting, strategic analyses and information for decision-making, among others. They help management acquire relevant information needed to make meaningful decisions (Alleyne\& Weekes-Marshall, 2011). Management accounting adapts to organizational change and three major forces cause organizations to evolve: technological change, globalization, and customer needs (McWatters, 2001). Competitiveness in the global market has led much organization to improve their management accounting practices and these necessary management accounting practices will help firms to improve continually. As a result of these all over the world there are so many management accounting tools \& techniques developed

\subsection{Organizational Performance}

According to Richard, Devinney, Yip, and Johnson (2009), organizational performance can be categorized into the following three specific areas of firm outcomes: (1) financial performance (profits, return on assets, return on investment, etc.); (2) market performance (sales, market share, etc.); and (3) shareholder return (total shareholder return, economic value added, etc.).

There is most empirical support for the association between management accounting practices and performance, with an increased use of non-financial information (Baines \& Langfield-Smith 2003; Chenhall \& Langfield-Smith, For example, Chenhall and Langfield-Smith (1998) point out that a greater use of advanced management accounting practices, such as quality improvement programs, benchmarking and activity based management, in firms that placed a strong emphasis on product differentiation strategies, ultimately results in high performance

Uyar (2010) noted that the perceived importance of cost accounting is driven by decreasing profitability, increasing costs and competition, and economic crises. The author also noted that while companies still perceive traditional management accounting tools as still important, new management accounting practices such as strategic planning, and transfer pricing are perceived less important than traditional ones. most study also found that the most important three management accounting practices are budgeting, planning and control, and cost-volumeprofit analysis. As presented earlier, performance may be an antecedent or an outcome factor of management accounting and organizational change. Prior studies show that there may be a link between performance and change. Low financial performance is said to be one of the reasons for the firm to change its management accounting and internal organizational factors to improve performance (Granlund, 2001 Laitinen (2006) supports this view, as he suggests that large changes in MAS may be associated with good financial performance.

\subsection{The Relationship between Management Accounting Practices and Performance}

Management accounting practice helps an organization to survive in the competitive, ever-changing world, because it provides an important competitive advantage for an organization that guides managerial action, motivates behaviors, supports and creates the cultural values necessary to achieve an organization's strategic objectives Gichaaga (2013). Ahmad and Zabri (2013) are of the view that research into management accounting practices (MAPs suggests that MAPs have important roles in ensuring the efficiency in the management of the firm and may also improve performance. Management accounting practices enable management to obtain relevant information for meaningful decision making (Alleyne and Weekes-Marshall, 2011, p. 49). Management accounting practices also permit firms to compete in the market place and reduce the likelihood of business failure (Mitchell \& Reid,2000, p. 385).

Gichaaga (2014) used a five -point Likert scale questionnaire featuring Costing System, Budgeting, Performance Evaluation, and Information for decision making and strategic analysis as the dimensions of management accounting practices. There were seven indicators under costing system, seven indicators under budgeting, six indicators under performance evaluation, ten indicators under information for decision making, and eight indicators under strategic analysis indicators under information for decision making, and eight indicators under strategic analysis. 
For comprehensiveness, this study adopts Gichaana's (2014) approach because it find its self in the same continent and of many similarities According to Hoque (2005), traditional performance measures are unable to satisfactorily reflect firm performance affected by today's changing business environment. Prior to Hoque (2005), Hoque, Mia, and Alam (2001), claimed that traditional measures which focus mainly on financial criteria such as return on investment or net earnings are narrow in focus, historical in nature and in many cases are incomplete.

The theoretical framework has provided a firm foundation upon which the relationship between management accounting practices and organizational performance can be studied. The empirical and conceptual review serves as the basis for comparison of the study findings, choice of the research design, analysis, and the focus of the study

From the empirical review it was learnt that prior research works in management accounting have examined the various relationships between the environment, organizational and management accounting system. Most of the studies have been qualitative in nature, just investigating which management accounting practices adopted by companies. Others too adopted a quantitative approach, examining the relationship between various management accounting practices and organizational performance. Most of the empirical literature was conducted in developed counties with just a hand full in Africa However, there has not been any Ghanaian study that examines the relationship between the various management accounting practices adopted by Ghanaian companies and organizational performance. This research is of view of intending to fill this gap by assessing the management accounting practices Used by manufacturing companies in Ghana.

\subsection{Conceptual Model and Hypothesis Development}

To empirically test the interrelationships between management accounting practices and Performance of manufacturing firms in Ghana a conceptual model is developed to Postulate on the management accounting and performance In this Conceptualized model, management accounting practices (costing system, budgeting, performance evaluation, information for decision making and strategic management accounting analysis) are the predictor variables while the determinants or agents that influence the choice of management accounting have also been operationalized as market competition, accounting staff, owner/management participation and Changes in technology.. Figure 1 depicts this conceptualized research model. The hypothesized relationships between the research constructs will be highlighted hereafter. 


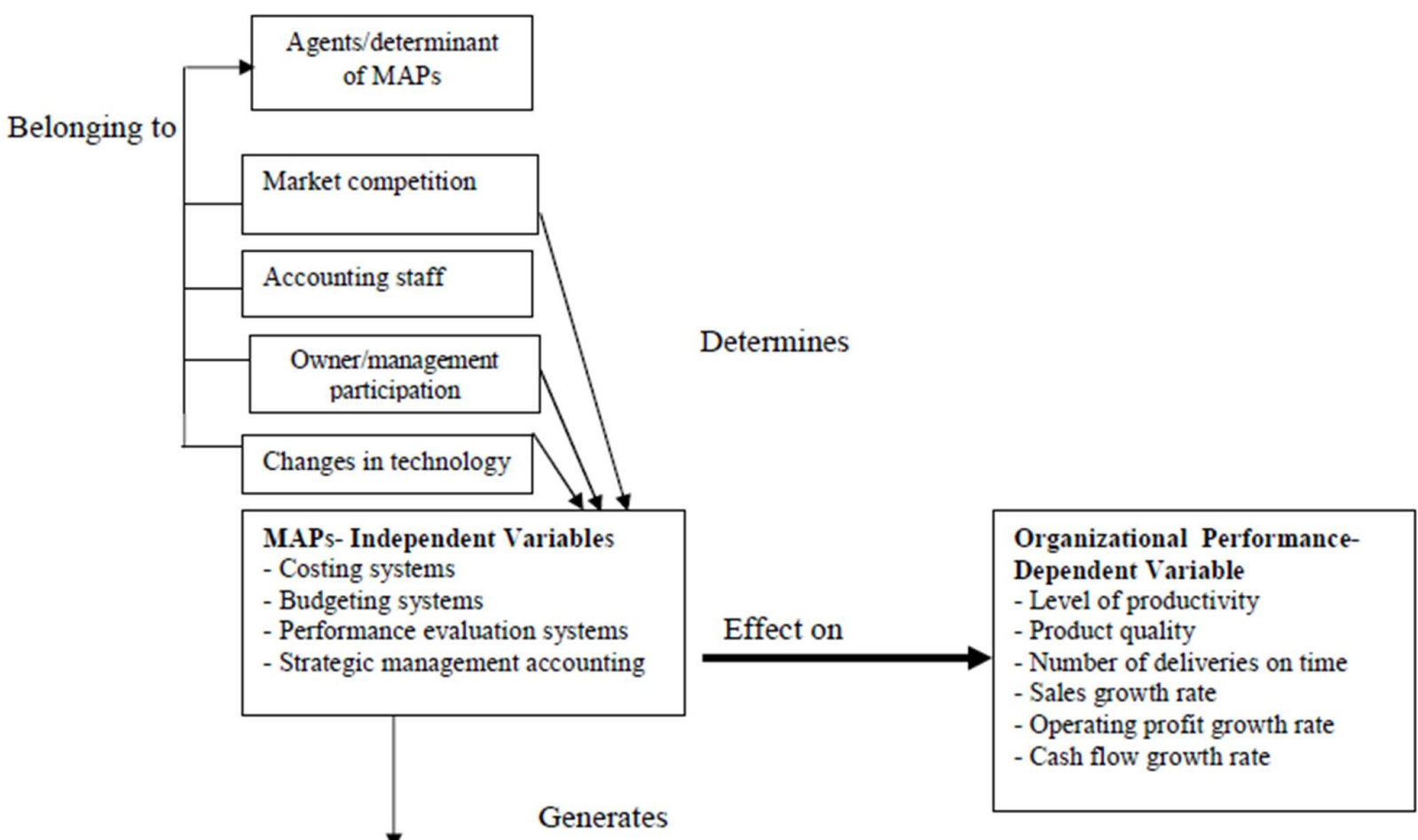

Figure 1: Management accounting practices and organizational performance Source: Authors construct 2020

$\mathrm{H} 0$ : There is no significant relationship between the performance of manufacturing firms and the management accounting practices adopted.

$\mathrm{H} 1$ : There is a significant relationship between the performance of manufacturing organizations and the management accounting practices adopted

\section{Methodology and Design of Research}

A quantitative research paradigm was use in conducting this study. A cross sectional survey method was adopted as the main methodology for the current research. The survey method was adopted since it allows the use of questionnaires to collect data and control bias as the participants was requested to relate their own perception free from the researcher's intervention (Mokoena \& Maziriri,2017; Dhurup, 2014).

\subsection{Target Population}

The target population for this study was 200 manufacturing companies in Ghana. Stratified random sampling method was applied to come up with the sample size, since the population in different manufacturing firms was considered heterogeneous, implying that a simple random sample is unrepresentative. This according to Cooper and Schindler (2006) 


\begin{tabular}{|l|l|}
\hline Sector & No of Firms \\
\hline Metals and allied & 10 \\
\hline Building & 10 \\
\hline Energy & 10 \\
\hline Food and Beverages & 80 \\
\hline Textiles & 2 \\
\hline Plastics & 15 \\
\hline motor & 3 \\
\hline paper & 12 \\
\hline Wood product & 10 \\
\hline Pharmaceutical & 15 \\
\hline Chemicals & 10 \\
\hline Leather & 5 \\
\hline Total & 200 \\
\hline
\end{tabular}

The study collected primary data from the respondents. The data collected was both quantitative and qualitative. Qualitative data is a categorical measurement expressed not in terms of numbers, but rather by means of a natural language description. Quantitative data is a numerical measurement expressed in terms of numbers. The study utilized a questionnaire to collect data. The questionnaire designed in this study comprised of two sections. The first part Information gathered in this section includes the type of business, number of years of operation, number of employees, and ownership structure of the business included the demographic and operational characteristics designed to determine fundamental issues including the demographic characteristics of the respondent. The second part was devoted to the questions on the management accounting practices being use and the effects it have on performance of manufacturing companies the performance evaluation practices were grouped into financial and non-financial measures. The questionnaire also asks respondent firms to indicate the level of benefits derived from the adoption of Management accounting practices or the usefulness of such practices. And lastly focuses on the factors that influence the adoption or use of management accounting practices.

\subsection{Statistical Tool and Method}

Questionnaires analysis is the process of bringing order, structure and meaning to the mass of information collected (Mugenda \& Mugenda, 2003). The SPSS statistical package version 18 was used as the statistical tool for the current research. The statistical method used is the standard multiple regression method. In testing the research hypothesis of the current research, standard multiple regression is used to explain the variance in the dependent variable (the adoption rate of management accounting practices) by a set of independent variables (the factors influencing the adoption of management accounting practices) and also the variance between performance and the adoption of management accounting practices.

\subsection{Conceptual Model}

The generic model can thus be stated as:

$Y=\alpha+\Sigma \beta \times+\varepsilon$

Where;

$\mathrm{Y}$ is the dependent variable

$\alpha$ is the constant (that is, all those variables not considered in the current study but which can result in a change in the dependent variable, $\mathrm{Y}$ )

$\beta$ is the coefficient of $x$

$\mathrm{x}$ refers to the independent variables

$\boldsymbol{\varepsilon}$ is the error term

Having stated the generic model, the equation can be operationalized to solve the

The conceptual model in this study is specified as follows:

$P f=\alpha+\beta 1 \mathrm{X} 1+\beta 2 \mathrm{X} 2+\beta 3 \mathrm{X} 3+\beta 4 \mathrm{X} 4+\beta 5 \mathrm{X} 5+\boldsymbol{\varepsilon}$

From the above equation;

The dependent variable is Performance $(P f)$.

The independent variables are:

Costing System (x1)

Level of Budgetary System (x2)

Performance Evaluation System (x3)

Strategic Analysis (x4)

Information for Decision making (x5)

The coefficients of these independent variables would be the bases for measuring how management 
accounting practices influence the level of organizational performance.

\subsection{Regression Analysis Results}

The results obtained in the regression analysis of the data collected from some selected manufacturing firms in Ghana are reported in

Table 2

\begin{tabular}{|c|c|c|c|c|c|}
\hline Variables & $\operatorname{Beta}(\beta)$ & t-stats & Std. Error & P-value & $\mathrm{R}^{2}$ \\
\hline Constant & & 3.764 & 0.650 & 0.000 & 0.623 \\
\hline Budgetary & 1.373 & 3.909 & 0.269 & $0.001 * * *$ & \\
\hline Costing systems & 0.566 & 2.078 & 0.269 & $0.045 * *$ & \\
\hline Strategic analysis & 0.390 & 1.679 & 0.231 & $0.073^{*}$ & \\
\hline Performance evaluation & 0.433 & 1.863 & 0.207 & $0.065^{*}$ & \\
\hline Information for decision making & 0.264 & 1.270 & 0.231 & 0.207 & \\
\hline
\end{tabular}

Total sums of square $(261.564)$

Sign. Level: $(* * *$ at $1 \%, * *$ at $5 \%, *$ at $10 \%)$

F-stat $89.317(0.000)$

Observation $=167$

In examining the relationship between the two variables, the study used standard multiple regression technique as recommended by Leech, Barrett and Morgan (2005) According to Friedman (2012) as well as Mafini and Meyer (2016) R-squared is a statistical measure of how close the data are to the fitted regression model and this is indicated by the percentage of variance. The higher the percentage of variance accounted for by the regression model, the closer it is to a perfect model fit of $100 \%$ (Mafini \& Meyer, 2016).

The $\mathrm{R}^{2}$ was relatively good $\left(\mathrm{R}^{2}=0.623\right)$, indicating that the fitness of the model used to examine the relationship. Thus the variables: budgetary system, costing system, strategic analysis, performance evaluation and information for decision making level account for about $62.3 \%$ changes in organizational performance with $37.89 \%$ other variable influencing changes in organization performance.

\section{Discussion}

The aim of this research was to investigate the impact of management accounting practices on the performance of manufacturing firms in Ghana the discussion focuses on the results of the regression analysis regarding the individual effects of the following management accounting practices (budgeting, costing system performance evaluation, strategic analysis and information for decision making on performance)

\subsection{Budgeting and Performance}

Looking at the regression analysis, budgeting was seen as statistical significant predictor and are such the most predictive power and therefore highly sensitive to organizational performance. Budgeting system has the strongest coefficient ( $\beta$ : 1.373; p-value: 0.001 ) showing that one percent upward in the level of budgetary control will impact organizational performance by 1.373 whiles a percentage downward in the level of budgetary control will affect organizational performance all other things being equal.

\subsection{Costing System and Performance}

Also Costing system as a management accounting practice was also a statistical significant predictor of performance with $(\beta=0.566 ; p=0.045)$ in the regression analysis. These findings show that costing system has a positive impact on business performance. which means that a percentage increase in the extent to which the respondents apply costing techniques will lead to 0.566 increase in organizational performance and vice-versa holding other variables constant These results are in line with a study conducted Elhamma and Zhang (2013) which found a costing system such as activity based costing results in a better performance for enterprises. Therefore to enhance performance, management strategies and policies should aim at improving the costing system

\subsection{Strategic Analysis and Business Performance}

Another management accounting practices that impacted performance is strategic analysis. Beta values showed strategic analysis was with a predictor of $(\beta=0.390 ; p=0.073$ this reveals that strategic analysis has positive impact on performance

\subsection{Performance Evaluation and Performance}

The coefficient for financial performance evaluation technique is 0.433 with a P-Value of 0.065 ). This also implies that an improvement in the extent of applying financial performance valuation technique will generate additional 0.433 increases in organizational performance of the respondents. On the other hand, should the level of application of financial performance evaluation technique be minimized or not being apply, organizational performance will 
accordingly reduce but by 0.433

\subsection{Information for Decision Making and Performance}

In the regression analysis results the study shows that a unit increase in Information for Decision Making practices will lead to an increase in performance by a factor of 0.264 with a $p$ - factor of 0.0207 ) these findings illustrate that information for decision making does have a significant impact on performance of manufacturing firms in Ghana but not that much as compare to other factors .

The whole results from the research approbate that management accounting system is an organizational change factor as we leant earlier from the institutional theory discussed The findings are consistent with the contribution of Burns and Scapens (2000) to Using institutional theory. Burns and Scapens were with the idea that management accounting change can be conceptualized as a change in organizational rules and routines which affect every aspect of the organization and this include organizational performance.

Again implication of the findings is that adoption of effective management accounting practice is a positive step toward improving the organizational performance of manufacturing sector. This is evident in the positive relationship between the level of management accounting practice and organizational performance. Furthermore, the study results support the institutional theory. The institutional theory suggests that there is a relationship between the level of Management accounting practices and organization performance (Burns \&Scapens, 2000). Moreover this study also proves that management accounting practices are organizational performance contingencies. According to the contingency theory, contingencies to a variable are those variables which significantly explain variations in the variable (Morton \& Hu, 2008). Therefore, the significant contribution of the management accounting variables to explaining variations in the level of organizational performance indicates that organizational performance is contingent on management accounting variables.

\section{SUMMARY, CONCLUSIONS AND RECOMMENDATIONS}

The study focused on management accounting practices and performance of manufacturing firms in Ghana this broad focus or general objective of the study was operationalized or narrowed to a specific objective. The study examined the relationship between management accounting practices and organizational performance of manufacturing firms in Ghana thus the impact management accounting practices have on manufacturing firms in Ghana. The study confirms that management accounting practices such as costing system, budgeting, performance evaluation, information for decision making and strategic analysis are agents that affect manufacturing firms performance in Ghana. This study contributes to the body of knowledge in the area of management accounting by providing current insights on both literature and research methodologies. In this manner the paper may be used as a reference source by future researchers on similar matters.

The study also brings into light a new direction in the research on management accounting practices by bringing on board for discussion on the importance of management accounting practices in the development of manufacturing firms in Africa

Based on the key findings and the various conclusions drawn the following recommendations are made: managers should periodically organize seminars and trainings to continually encourage its players alsomanufacturing firms should effectively design and implement management accounting systems. Encourage managers and owners within the manufacturing sector to participate actively in the implementation management accounting systems as this would enhance the extent of management accounting practice. Manufacturing firms are encouraged to: Continually review their management accounting practices to assess their effectiveness and address any known inefficiency as they have direct bearings on the performance and also employ experts to help them in this regard.

The study was with the limitation of only concentrating on the management accounting practices of manufacturing companies in Ghana and not all the companies in the economy. These results are therefore only limited to the manufacturing companies and may be of little or no use to the companies in other sectors in the country

\section{References}

Abdel-Kader, M. G., \& Luther, R. (2004).An empirical investigation of the evolution of management accounting practices. Department of Accounting, Finance and Management.

Abdel-Kader, M. G., \& Luther, R. (2006).Management accounting practices in the British food and drinks industry. British Food Journal, 336-357.

Abdel-Kader, M. G., \& Luther, R. (2008). The impact of firm characteristics on management accounting practices: A UK-based empirical analysis. The British Accounting Review, 40 (1), 27.

Abdul Rahman, I.K., Tew, Y.H., \& Omar, N. (2002).Management accounting practices of small and medium industries (SMI) in Malaysia: A preliminary study, Paper Presented at The Asian Management Accounting Forum, in Fukuoka, Japan, November 1-4. 
Acquaah, M. (2013). Management control systems, business strategy and performance: A comparative analysis of family and non-family businesses in a transition economy in sub-Saharan Africa. Journal of Family Business Strategy, 4(2), 131-146.

Adler, R., Everett, A. M., \& Waldron, M. (2000).Advanced management accounting techniques in manufacturing: utilization, benefits, and barriers to implementation. Accounting Forum 24 (2), 131-150. Association of Ghana Industries Business Barometer Report, 2013.

Ajibolade, S. O. (2013). Management accounting systems design and company performance in Nigerian manufacturing companies: A contingency theory perspective. British Journal of Arts and Social Sciences, $14(2), 228-244$.

Ahmad, K. (2012). The use of management accounting practices in Malaysian SMEs. (Unpublished Doctoral Thesis, University of Exeter).

Akoto, R. K., Awunyo-Vitor, D., \&Angmor, P. L. (2013). Working capital management and profitability: Evidence from Ghanaian listed manufacturing firms. Journal of Economics and International Finance, 5(9), 373

Allahyari, A., \&Ramazani, M. (2011).Firm technological change and its effects on management accounting change (Case study of Iranian Manufacturing Firms). Global Journal of Management and Business Research, $11(9)$.

Alleyne, P., \& Weekes-Marshall, D. (2011).An exploratory study of management accounting practices in manufacturing companies in Barbados .International Journal of Business and Social Science, 9 (2), 49-58.

Amidu, M., Effah, J., \&Abor, J (2011).E-Accounting practices among small and medium enterprises in Ghana. Journal of Management Policy and Practice, 12(4).

Amoako, G. K. (2013). Accounting practices of SMEs: A case study of Kumasi Metropolisin Ghana. International Journal of Business and Management; 8, (24).

Anand, M., Sahay, B. S., \&Saha, S. (2004). Cost management practices in India: An empirical study. ASCI Journal of Management, 33(1-2), 1- 13.

Ashton, D., Hopper, T., \&Scapens, R.W. (1991).Issues in management accounting, Hemel Hempstead, PrenticeHall.

Ashton, D., Hopper, T., \&Scapens, R. (1995). The changing nature of issues in management accounting, Hertfordshire .Prentice Hall.

Ayodele, S. A., \&Falokun, G. O. (2003). Nigeria"e s Financial and Monetary Systems: The Capital Market. the Nigerian Economy-Structure and Pattern of Development, 26-153.

Baird, K., Jia Hu, K., \& Reeve, R. (2011).The relationships between organizational culture, total quality management practices and operational performance. International Journal of Operations \& Production Management, 31(7), 789-814.

Battilana, J., \&Casciaro, T. (2012). Change agents, networks, and institutions: A contingency theory of organizational change. Academy of Management Journal, 55(2), 381-398.

Baines, A., \&Langfield-Smith, K. (2003). "Antecedents to management accounting change: A structural equation approach”, Accounting, Organizations and Society, 28 (7-8), 675-698.

Barnett, W. P., \&Caroll, G. R. (1995). Modeling internal organizational change. Annual Review of Sociology, 21, 217-236.

Betts, S. C. (2011). Contingency theory: Science or technology? Journal of Business \& Economics Research, 1(8).

Bloom, N., \& Van Reenen, J. (2010). Why do management practices differ across firms and countries?. The Journal of Economic Perspectives, 24(1), 203-224.

Bromwich, M., \&Bhimani, A. (1994).Management accounting: Pathways to ’progress, London: Chartered Institute of Management Accountants

Brownell, P. (1995). Research methods in management accounting. Melbourne: Coopers and Lybrand.

Brunetti, A., Gregory, K., \& Beatrice, W. (1997)."Institutional obstacles to doing business: Region-by-region results from a worldwide survey of the private sector," World Bank PRD Working Paper 1759.

Bryman, A. (2008). Social research methods, (3rded). New York: Oxford.

Burns, J., \&Scapens, R. W. (2000).Conceptualizing management accounting change: An institutional framework. Management Accounting Research, 11(1), 3-25.

Burns, J., Ezzamel, M., \&Scapens, R.S. (1999).Management accounting change in the UK. Management Accounting, 77(3), 28-30.

Burns, J., \&Vaivio, J. (2001).Management accounting change. Management Accounting Research, 12(4), 389402.

Chenhall, R. (2007). Theorising Contingencies in Management Control Systems Research. In C. Chapman, A. Hopwood \& M. Shields (Eds.)

Chenhall, R. H., \&Langfield-Smith, K. (1998).Adoption and benefits of management accounting practices: An Australian study. Management Accounting Research, 9(1), 1-19. 
Chenhall, R. H., \&Langfield-Smith, K. (1998). The relationship between strategic priorities, management techniques and management accounting: An empirical investigation using a systems approach. Accounting, Organizations and Society, 23(3), 243-264.

Chenhall, R., H., \&Langfield-Smith, K. (1998).Factors influencing the role of management accounting in the development of performance measures within organizational change programs. Management Accounting Research, 9(4), 361-386.

Chenhall, R.H., Morris, D. (1986). "The impact of structure, environment, and interdependence on the perceived usefulness of management accounting systems", The Accounting Review, 61, 16-35.

Chenhall, R. H. (2003). Management control systems design within its organizational context: Findings from contingency-based research and directions for the future. Accounting, Organizations and Society, 28, $127-$ 168.

Collis, J., \& Hussey, R. (2003).Business research: A practical guide for undergraduate and postgraduate students. 127

Cooper, R., \& Kaplan, R.S. (1991a). "Profit priorities from activity-based costing”, Harvard Business Review, $69,130-5$

Creswell, J. (2003), Research design: Qualitative and quantitative approaches, (2nded). California, Thousand Oaks.

Danese, P. (2011).Towards a contingency theory of collaborative planning initiatives in supply networks. International Journal of Production Research, 49(4), 1081-1103

Donaldson, L. (2006). The contingency theory of organizational design: Challenges and opportunities. Journal of Organization Design, 19-40.

Donaldson, L. (2001). The contingency theory of organizations, Sage, California, Thousand Oaks.

Eccles, R.G., \&Nohria N. (1992).Beyond the hype: Rediscovering the essence of management, Boston: Harvard Business School Press.

Easterby-Smith, M., Thorpe, R., \& Lowe, A. (2002).Management research, London: (2nded) Sage Publications.

Erzan, R., Kuwahar, K., Sarafino, M., \& Renee, V. (1989). "The profile of protection in developing countries," UNCTAD Rev.,1(1), 29-49.

Feilzer, M. Y. (2010). Doing mixed methods research pragmatically: Implications for the rediscovery of pragmatism as a research paradigm. Journal of mixed methods research, 4(1), 6-16.

Francis, T. (1999).The Ghanaian manufacturing sector 1991-95: Firm growth, productivity and convergence, The Journal of Development Studies, 36:1, 109-127.

Gathungu, J. M., \&Owanda, W. A. (2012). Performance contracting strategy, public sector reforms and performance of public institutions in the transport sector in Kenya. International Journal of Arts and Commerce, 1(3), 1-9.

Gelso, C. J. (2006). Applying theories to research: The interplay of theory and research in science. In Leong, F.T., \&Austin J. T. (Eds.).The Psychology research handbook. Thousand Oaks, CA: Sage.

Gerdin, J. (2005). "Management accounting system design in manufacturing departments: An empirical investigation using a multiple contingencies approach", Accounting, Organizations and Society, 30, 99-126.

Gichaaga, P. M. (2013). Factors affecting implementation of the strategy in the water sector reforms in Kenya: A census of contracted water services providers by Tana Water Services Board (Doctoral dissertation).

Gichaaga, P. M. (2014). Effects of management accounting practices on financial performance of manufacturing companies in Kenya

(Unpublished Doctoral dissertation).University of Nairobi, Nairobi. Golicic, S. L., \& Smith, C. D. (2013).A metaanalysis of environmentally sustainable supply chain management practices and firm performance. Journal of supply chain management, 49(2), 78-95.

Gordon, L.A., \& Miller, D. (1976).A contingency framework for the design of accounting information systems. Accounting, Organizations and Society, 1, 59-69.

Granlund, M. (2001). Towards explaining stability in and around management accounting systems. Management Accounting Research. 2001. 141-166.

Hair, J., Babin, B., Money, A., \&Samuel, P. (2003).Essentials of business research methods. .

Hair, J.F.J., Money, A.H., Samouel, P., \& Page, M. (2007).Research method for business. U.S: Wiley.

Haldma, T., \&Lääts, K. (2002).Contingencies influencing the management accounting practices in Estonian manufacturing companies , Management Accounting Research, 13 (4), 379-400.

Harlow, E. (2009). Contribution theoretical.Encyclopedia of case study research. Thousand Oaks, CA: Sage. Retreived from http://www.sageereference.com/ case study/Article_n89.

Hawkes, L. C., Fowler, M., \& Tan, L. M. (2003).Management accounting education: Is there a gap between academia and practitioner perceptions? Discussion Paper Series 215.

Henri, J. F., \& Journeault, M. (2010). Eco-control: The influence of management control systems on environmental and economic performance. Accounting, Organizations and Society, 35(1), 63-80. 
Hilton, R. W., \& Platt, E. David (2011).Managerial accounting: Creating value in Global business Environment. (9thed).McGraw Hill International Edition.

Hilton; R.W. Maher; M.W Selto; F.H. (2000).Cost management: Strategies for business decision. New York: McGraw Hill.

Hopper, T. (2000), "Management accounting in less developed countries", CIMA Research Update, Autumn/Winter, pp. 6-7.

Hopper, T., Tsamenyi, M., Uddin, S., \&Wickramasinghe, D. (2004). "The state they're in: Management accounting in developing countries”, Financial Management, CIMA, June, pp.14-19

Hoque, M. Z. (2004). Flawed working capital loan policy and loan default: Evidences from Bangladesh, Journal of Accounting, Business and Management, 11, (2), 202-213.

Hoque, Z. (2005). Linking environmental uncertainty to non-financial performance measures and performance: A research note. The British Accounting Review, 37(4), 471-481.

Hoque, Z., Mia, L., \&Alam, M. (2001). Market competition, computer-aided manufacturing and use of multiple performance measures: An empirical study. The British Accounting Review, 33(1), 23-45.

Horngren, C., Sundem, G., Stratton, W., Burgstahler, D., \&Schatzberg, J. (2007). Introduction to management accounting (14th ed.), New Jersey: Pearson Prentice Hall

Horngren, C.T., Datar, S., Foster, G., Rajan, M., \&. Ittner, C. (2009). Cost accounting: A managerial emphasis. (13thed), New Jersey, Upper Saddle River: Prentice Hall.

Hubbard, G. (2009). Measuring organizational performance: beyond the triple bottom line. Business strategy and the environment, 18(3), 177-191.

Hyvonen, J. (2007). Strategy, performance measurement techniques and information technology of the firm and their links to organizational performance. Management Accounting Research, 18 (3), 343-366.

Innes, J., \& Mitchell, F. (1991). “ABC: a Survey of CIMA Members”, Management Accounting (UK), 69, (9), 2830.

Innes, J., \& Mitchell, F. (1990).The process of change in management accounting: Some field study evidence. Management Accounting Research, 1, 3-19.

Innes, J., \& Mitchell, F. (1995).A survey of activity based costing in the UK's large companies. Management Accounting Research, 6(2), 137-153.

Ittner, C., \&Larcker, D. (2002).Empirical managerial accounting research: Are we just describing management

Laitinen, E.K., (2002). A dynamic performance measurement system: Evidence from small finish technology companies. Scandinavian Journal of Management. 18. 1. 65-99.

Lapsley, I., \&Pallot, J. (2000). "Accounting, management and organizational change: A comparative study of local government. "Management Accounting Research 11 (2): 213-229.

Leftesi, Abdulghani (2008). The diffusion of management accounting practices in developing countries: Evidence from Libya. Unpublished Doctoral thesis, University of Huddersfield.

Liaqat, A. (2006). Applications of contemporary management accounting techniques in Indian industry. Chartered Management Accountant, 64(8), 8-13.

Libby, T., \& Waterhouse, J.H. (1996).Predicting change in management accounting systems. Journal of Management Accounting Research, 1 (8): 137-154.

Ma, Y. \&Tayles, M. (2009). "On the emergence of strategic management accounting: an institutional perspective”, Accounting and Business Research, 39, 473-495.

Mbawuni, J. \&Anertey, A. R. (2014).Exploring management accounting practices in emerging telecommunication market in Ghana. Accounting and Finance Research 3, (4).

McWatters, C. S., Morse, D. C., \& Zimmerman, J. L. (2001).Management accounting: Analysis and interpretation. New York: McGraw- Hill/Irwin.

Mikes, A., \& Kaplan, R. S. (2013).Towards a contingency theory of enterprise risk management.

Moores, K., \& Yuen, S. (2001). Management accounting systems and organization configuration: A life-cycle perspective. Accounting, Organizations and Society, 26, 351-389.

Morton, N. A., \& Hu, Q. (2008).Implications of the fit between organizational structure and ERP: A structural contingency theory perspective. International Journal of Information Management, 28(5), 391-402.

$\mathrm{Ng}$, Francis. (1996). "A profile of tariffs, para-tar-iffs, Non-tariff measures, and economic growth in developing countries," World Bank, International Trade Division.

Nishimura, A. (2002). Asia economic growth and management accounting. Malaysian Accounting Review, 1(1), 87-101.

Obed, A. Y. (2016).A failing manufacturing sector.http://thebftonline.com/business/economy/17729/afailingmanufacturing- sector-.html

Okoli, C. \&Schabram, K. (2010). "A guide to conducting a systematic literature review of information systems research, Sprouts: Working Papers on Information Systems, 10(26). http://sprouts.aisnet.org/10-26

Omar, N., Abdul Rahman, I. K., \&Zainal, A. Z. (2002).The application of management accounting techniques in 
Malaysia companies. A paper presented at The Asian Management Accounting Forum. Fukuoka, Japan, 20819.

Otley, D. (1980), The contingency theory of management accounting: Achievement and prognosis. Accounting, Organizations and Society, 5, 413-428.

Parker, L. D. (2002).Budgetary incrementalism in a Christian bureaucracy. Management Accounting Research, 13(1), 71-100.

Perera, S., Harrison, G., \& Poole, M. (1997).Customer-focused manufacturing strategy and the use of operationsbased non-financial performance measures: A research note. Accounting, Organization and Society, 22 (6): 557-572.

Richard, P. J., Devinney, T. M., Yip, G. S., \& Johnson, G. (2009).Measuring organizational performance: Towards methodological best practice. Journal of management.Vol.35, No.3, p.718-804

Saunders, M., Lewis, P., \&Thornhill, A. (2009).Research methods for Business Students, (5thed). England: Pearson Education Ltd.

Schiff, M. \& Alberto, V. (1992).The political economy of agricultural pricing policy. Vol. 4: A Synthesis of the Economics in Developing Countries. Baltimore: Johns Hopkins University Press.

Wiley \& Sons, Inc. Shields, M. D. (1997).Research in management accounting by North Americans in the 1990s. Journal of Management Accounting Research, 9, 3-61.

Sim, K. L., \&Killough, L.N. (1998).The performance effects of complementarities between manufacturing practices and management accounting systems. Journal of Management Accounting Research 24: 325-346.

Sisaye, S. (2003).Process innovation and adaptive institutional change strategies in management control systems: Activity based costing as administrative innovation. Advances in Management Accounting, 11, 251-285.

Smith, M. (2009).Management accounting for competitive advantage. Sydney: LBC Information Services.

Smith, M., Abdullah, Z., \& Abdul-Razak, R. (2008).The diffusion of technological and management accounting innovation: Malaysian evidence. Asian Review of Accounting, 16(3), 197-218.

Sulaiman, M. B., NazliNik Ahmad, N., \&Alwi, N. (2004).Management accounting practices in selected Asian countries: A review of the literature. Managerial Auditing Journal, 19(4), 493-508.

Sulaiman, S., \& Mitchell, F. (2005).Utilising a typology of management accounting change: an empirical analysis. Management Accounting Research. 16, 422-437.

Sunarni, C. W. (2013). Management accounting practices and the role of management accountant: Evidence from manufacturing companies throughout Yogyakarta, Indonesia. Review of Integrative Business \& Economics Research, 2(2), 616-626.

Teal, F., Habyarimana, J., Thiam, P., \& Turner, G. (2006). Ghana: An Analysis of Firm Productivity (pp. 1-72). Regional Program on Enterprise Development, The World Bank: Washington DC

Tillema, H.H. (2005). Pressure for renewal: The intricate relationship of facilitators and consumers of education. Teachers \& Teaching, 11(1), 119-124.

Tomasz Wnuk-Pel. (2011). Innovations in management accounting at the turn of the 20th and 21st century, Folia Oeconomica 257.

Tybout, J. R. (2000). Manufacturing firms in developing countries: How well do they do, and why? Journal of Economic Literature, 108, 11-44.

Taylor, A., \& Taylor, M. (2014). Factors influencing effective implementation of performance measurement systems in small and medium-sized enterprises and large firms: a perspective from Contingency Theory. International Journal of Production Research, 52(3), 847-866.

Uyar, A. (2010). Cost and management accounting practices: A survey of manufacturing companies. Eurasian Journal of Business and Economics, 3 (6), 113-125.

Van Triest, S. \&Elshahat, M. (2007). "The use of costing information in Egypt: A Research Note”, Journal of Accounting and Organizational Change, 3 (3), 329-343.

Vokurka, R. J., \&Lummus, R. R. (2001).At what overhead level does activity based costing pay off ?Production and inventory management journal, 42(1), 40.

Waldron, M. (2005).Overcoming barriers to change in management accounting systems. Journal of American Academy of Business 2, 244- 249.

Waterhouse, J. H. \&Thiessen, P. (1978). "A contingency framework for management accounting research", Accounting, Organizations and Society, 3 (3), 65-76.

Waweru, N. M. (1999). A survey of management accounting practices by publicly quoted companies in Kenya (Unpublished Doctoral dissertation, University of Nairobi).

Waweru, N. M., Hoque, Z., \&Uliana, E. (2004).Management accounting change in South Africa. Accounting, Auditing \& Accountability Journal, 17(5), 675-704. 